\title{
CRIADOR E CRIATURA EM A MENINA MORTA E FRANKENSTEIN
}

Josalba Fabiana dos Santos

UFS

O clima geral em A menina morta (1954), de Cornélio Penna (1896-1958), é de mistério, não só por aquilo que se conta, a narrativa propriamente dita, mas pelo como se conta, a narração, que revela encobrindo, que afirma sem dizer, que deixa ao leitor o papel de decifrador de enigmas, se não quiser ser devorado pela dúvida. Diferentemente dos romances anteriores do autor - Fronteira (1935), Dois romances de Nico Horta (1939) e Repouso (1948) -, A menina morta é o único que não se passa numa cidade. Localizada numa fazenda produtora de café no Segundo Império, a casa dos Albernaz se mantém isolada, além de suas dimensões gigantescas e do aspecto arruinado que assinala o final da narrativa: ambiente propício para se ver passar fantasmas em pleno dia, como afirma uma das personagens. Tais características levaram alguns críticos a aproximar a obra corneliana do romance gótico. Para Luiz Costa Lima é difícil entender que A menina morta seja de 1954, pois não tem contato com a produção contemporânea, o que leva o crítico a pensar num vínculo com o romance gótico (LIMA, 1976: p.56). Marília Rothier Cardoso menciona traços da tradição fantástica e do gótico (CARDOSO, 2001). E Léo Schlafman, ao tratar de Itabira, a cidade mineira onde se desenvolve a narrativa de Fronteira, afirma que Cornélio Penna encontra ali "as premissas do gótico" (SCHLAFMAN, 2001: p.14).

Longe de se pensar na obra corneliana como gótica, trata-se de tentar compreender o "clima fantasmal" (LIMA, 2005: p.11) e o "mundo monstruoso" (LIMA, 2005: p.15) que a circula. Nessa medida, os traços do gótico são mais importantes do que a estética em si. É visível que, especialmente em A menina morta, o gótico não é um fim, mas apenas um instrumento que encobre a violência do patriarcalismo escravocrata no Brasil do século 19. O Grotão, nome da propriedade onde se desenvolve a narrativa, detém mais de uma centena de cativos que são regidos pelas mãos firmes do Comendador, o pater familias. Haveria uma aparente harmonia entre os moradores, que se esfacela com a morte da filha mais nova. Mais tarde o leitor perceberá que nem mesmo a menina quando viva fora realmente capaz de pacificar os ânimos, inclusive porque seria absurdo esperar que uma criança resolvesse um problema que não se limitava às fronteiras da fazenda. 
A morte da filha mais nova da família, não se sabe em quais circunstâncias, é o primeiro aspecto lúgubre a se destacar e é anunciado logo nas primeiras linhas da narrativa. Dona Virgínia, uma parenta agregada, acusa Dona Mariana, a mãe, de negligência:

Não sei como se pôde abandonar uma criança assim, meu Deus! - e as palavras ciciavam um pouco, pareciam sair dos cantos da boca, pois a prendia ao meio com o dente - não sei... o coração de monstro não conseguiu guardar este tesouro! Ainda se vê ser menina destinada a tornar-se mulher robusta, capaz de ter muitos filhos e fundar outra fazenda maior que esta! Não há justiça neste mundo... não... (PENNA, 1997: p.22 - grifo meu)

Apenas uma mãe pouco consciente da sua função permitiria que sua filha morresse. Monstro é sinônimo de deformação, logo "coração de monstro" indica uma deformidade, uma anomalia assustadora. Dona Mariana teria assim um coração, órgão simbolicamente associado à expressão dos sentimentos, fora do normal. "Normal" seria uma mãe afetuosa e sobretudo que preservasse a vida de seus filhos. Segundo Dona Virgínia, não foi isso o que a Senhora fez. E essa passagem revela mais: anuncia um projeto de continuidade do patriarcalismo. A menina deveria crescer para se tornar uma proprietária, para ter uma fazenda ainda maior do que a dos seus pais, com mais escravos e, portanto, mais exploração. Sua morte, da qual a mãe é aqui acusada, interrompe o projeto. Portanto, para Dona Virgínia, aliada do Comendador, o pai da criança, houve mais do que negligência: Dona Mariana teria destruído a possibilidade de o sistema se perpetuar. A menina cresceria e se tornaria uma fazendeira reprodutora de filhos, logo reprodutora do patriarcalismo, o que sua mãe não fora. Não porque Dona Mariana não tivesse filhos, mas porque não compactuava com as idéias do marido, o Comendador.

Num certo sentido, A menina morta guarda semelhanças com o mito do criador e da criatura estabelecido em Frankenstein (1818) - mito que superou o romance, considerado gótico, de Mary Shelley (1797-1851), que o gerou: criatura/criação que superou a criadora. Essa superação é evidente não só na narrativa, que é suplantada por inúmeros filmes, mas inclusive na história propriamente dita, quando o nome do criador é transposto para a criatura. Transposição que não é feita nem pela autora nem pelo genitor ficcional, que, incapaz de apreender sua obra, jamais a nomeia. A identidade de Frankenstein é transferida para sua criação por aqueles que conhecem muito mais o 
mito do que o romance de Shelley. Embaralhamento de identidades que faz sentido, pois, afinal, quem é o monstro e quem é a vítima em Frankenstein? A monstruosidade da criatura é bastante evidente na aparência física, no horror que causa e nas atitudes, por meio dos assassinatos que acumula. Já o cientista tem aparência comum e não é um assassino, no entanto é ele quem pensa e formula o mal: a criação monstruosa.

Dona Mariana e Frankenstein se assemelham: são monstros porque geram monstruosidades. A Senhora do Grotão teve duas filhas que, como a mãe, também são monstruosas. O corpo morto da filha mais nova causa horror à já mencionada Dona Virgínia e a Celestina, outra agregada e prima de Dona Mariana:

Surgiria diante delas um rosto inchado, deformado pelo calor e pela podridão que decerto já se procedia ali dentro, no afã de transformar o anjo que elas tinham vestido e perfumado com água de alfazema em um monstro repelente? (PENNA, 1997: p.52 - grifo meu)

A metamorfose - no caso, de anjo em monstro repelente - é também uma monstruosidade (NAZÁRIO, 1998: p.40). Transformando-se com freqüência, o monstro se torna de difícil compreensão e de difícil apreensão. Isso tudo só multiplica o seu poder de destruição. E “o monstro na ficção de horror não só é letal como também - e isso é da maior importância - repugnante" (CARROLL, 1999: p.39), ainda que não se possa dizer que o romance corneliano se configure como ficção de horror, como também não se disse que era um legítimo exemplo de gótico. Viva, a criança era um anjo, mas, morta, torna-se um repulsivo monstro. A morte é abjeta porque expele líquidos e odores desagradáveis. Além disso, transforma e decompõe os corpos. Não se pode reconhecer um ser amado num corpo morto depois de algum tempo. A forma como é comumente tratada, um oxímoro, - menina morta - coloca a criança numa zona intersticial, porque menina remete à vida, mas morta é o seu contrário. Está no território das impurezas que fazem com que se torne de repente asquerosa. Afirma-se quando da morte da criança que "soara a última hora do Grotão". O monstro funciona como uma advertência (COHEN, 2000: p.27), a de que um limite foi ultrapassado (COHEN, 2000: p.42-43). Transformar homens livres em escravos é o principal índice desse limite rompido. A menina dá um aviso e a irmã, Carlota, complementa a tarefa monstruosa: destrói, arruína (NAZÁRIO, 1999: p.16). Destruir é a tarefa básica de qualquer monstro. Ao contrário da criança, Carlota não chega a ser nomeada diretamente como monstro, mas a sua transformação radical e as suas atitudes causam temor naqueles que a cercam. 
De filha resignada a um casamento arranjado pelo pai, passa a revoltada com o patriarcalismo escravocrata. Recusa-se ao matrimônio imposto e liberta a todos os escravos da fazenda. Portanto, ela é monstruosa para o sistema porque o destrói. As mudanças são tão radicais que chegam a assustar a própria Carlota:

Não podia sequer mover os pés que lhe pareciam agora monstruosos e era com medo que sentia qualquer coisa extraordinária e brutal violar-lhe o coração. Com esforço conseguiu andar e seus vestidos varreram o caminho, como um grande manto que se arrastasse pelo chão, despedaçando-se nas pontas das pedras e nos espinhos das moitas, e deixavam atrás de si farrapos negros, salpicados de pequeninas frutas selvagens e rubras semelhantes a gotas de sangue... Entretanto, ergueu a cabeça, e todo o seu corpo vibrou com surda e irreprimível alegria e a convicção inescrutável de que espalhava a morte e a ruína em torno dela, a encheu de sinistro orgulho. (PENNA, 1997: p.463)

Se, por um lado, se insiste nas semelhanças existentes entre Dona Mariana e Frankenstein, por outro, é impossível não perceber uma identificação entre esse momento de júbilo destrutivo de Carlota e a criatura afirmando que "desejava pôr abaixo as árvores, espalhar devastação e destruição (...), para então contemplar satisfeito as ruínas" (SHELLEY, 2006: p.152). E, principalmente, após matar o irmão mais novo do seu criador, quando se sente ainda mais terrível: "Contemplei a vítima, e meu coração encheu-se de júbilo com o triunfo infernal (...)" (SHELLEY, 2006: p.159). Para Carlota, os pés monstruosos são os agentes da destruição que espalha com "sinistro orgulho". O que ela deixa atrás de si são os vestígios da própria família. A alforria dada aos cativos do Grotão e o cancelamento do matrimônio impossibilitam a continuidade do sistema patriarcal escravocrata: a riqueza se esgotara. Como a criatura de Frankenstein, Carlota se volta contra o seu criador, o Comendador, mas não contra a sua criadora.

A menina e Carlota são tão ou mais monstruosas do que a mulher que as gerou. Dona Mariana é uma figura ambígua que cria (as filhas) e ao mesmo tempo destrói. Ou melhor, contribui para a destruição através das criaturas aniquiladoras que gerou. Ao contrário de Frankenstein, que tenta destruir a própria criação, a Senhora tem como alvo o patriarcalismo escravocrata que aprisiona a ela e a sua prole. Como a narrativa em Cornélio Penna não é direta, mas labiríntica, seus verdadeiros objetivos não ficam claros num primeiro momento nem para o leitor, nem para suas crias. Na verdade, ela jamais 
verbaliza seus pensamentos. A imagem impressa na memória da filha mais velha só depõe contra a Senhora do Grotão:

diante (...)(de Carlota) surgiu a cadeira de balanço, com dragões esculpidos e veio logo à sua lembrança a figura mutilada de rainha distante, desdenhosa, de quem não era possível aproximar-se sem provocar irritação e gestos de defesa. Era sempre a mesma sensação de sacrilégio que fazia seus dedos se encolherem, suas mãos estendidas para um carinho caírem desanimadas, e sua boca sequiosa de um contato quente fecharse, apertados os lábios até ficarem lívidos. (PENNA, 1997: p.290)

Dona Mariana surge outra vez como indiferente aos estereótipos da maternidade abnegada. Quando comparada a uma "rainha distante" e "desdenhosa", sua descrição se agrava, porque, pior do que uma mãe má, é como se não fosse uma mãe, pois está psicológica e hierarquicamente distante. As iniciativas de contato são da filha, que, no entanto, não as realiza, pois se sente insegura e percebe que não haverá correspondência. Sentada numa cadeira "com dragões esculpidos" - seres monstruosos que são representados como se fossem guardiões -, a Senhora está ainda mais protegida dos importunos - e os filhos estariam entre os importunos. Além disso, a cadeira é de balanço, fato que dificulta qualquer aproximação. Dona Mariana é inapreensível porque oscilante - e oscilante porque inapreensível. Sua imagem é metonímica, "figura mutilada". Carlota não tem dela uma idéia de totalidade, apenas os vestígios da memória permanecem. Com a menina morta, como é sempre tratada a criança, as coisas não foram melhores:

Todos se preocupavam com a criança, robusta e alegre, e assim ninguém notou a mudança que se operava rapidamente na vida dos senhores. Dona Mariana, cada vez mais silenciosa, como ausente, sem escutar nunca o que lhe diziam, retirando-se do governo da casa, e até mesmo, e Libânia (uma mucama) estremeceu ao recordá-lo, até mesmo a mostrar-se indiferente para com a menina... (PENNA, 1997: p.381)

A transformação que a escrava percebe em Dona Mariana para com a criança já havia sido constatada pela filha mais velha há anos. A menina morta e Carlota, e os dois filhos homens, deviam representar para a Senhora a continuidade do patriarcalismo escravocrata, daí o distanciamento. Todos eram educados - não pela mãe - para perpetuar o sistema, como se viu na fala de Dona Virgínia, referente à filha mais nova: 
"Ainda se vê ser menina destinada a tornar-se mulher robusta, capaz de ter muitos filhos e fundar outra fazenda maior que esta!" (PENNA, 1997: 22). Dona Mariana não via nos seus filhos uma possibilidade de resistência ao marido. Mas, surpreendentemente, as filhas mulheres resistem. A menina menos, é mais titubeante entre o pai e a mãe, o que se explica facilmente pela sua pouca idade.

A resistência da própria Senhora pode não parecer assim tão evidente. Joviana, uma mucama, recorda-se dela na infância e tem uma imagem reveladora e oposta às anteriormente assinaladas: "Era a menina imperiosa, altiva, sequiosa de verdade e justiça (...)" (PENNA, 1997: p.343). Essa breve afirmativa, feita pela voz sempre desautorizada das escravas, desautorizada pelo Comendador, é reveladora de uma outra faceta de Dona Mariana. O desejo de justiça, demonstrado desde a infância, denota que sua altivez, tantas vezes mencionada na narrativa, nada mais era do que indignação, especialmente se for lembrado que não se permitia circular pelo eito - local do trabalho exaustivo dos escravos e domínio do Senhor.

Deviam andar pelos campos sem cultura para evitar sempre, com todo o cuidado, os eitos, porque a Sinhá não gostava de ver os negros no trabalho, e dava ordens ríspidas quando viam ao longe o grupo de homens, seguidos pelo capataz, ou ouviam trazido pelos ventos o canto lamentoso dos que cavavam. (PENNA, 1997: p.18-19)

Posta logo no início da narrativa e somada a outras passagens desabonadoras, essa citação pode dar uma idéia bastante negativa de Dona Mariana. Mas relida à luz das palavras de Joviana, nas quais o desejo de verdade e de justiça se sobrepõe, observase que a distância exigida dos trabalhadores nada tem a ver com afetação. Longe dos negros e mulatos nos momentos em que são explorados, a Senhora se aproxima ao manter uma capela de aspecto primitivo numa clareira da mata que também é cultuada por eles. O trabalho árduo é associado ao Comendador, enquanto o lado não cultivado da fazenda, onde a floresta domina, é associado à Senhora.

Além de mover guerra ao patriarcalismo e à escravidão, sintetizados na figura do Comendador, Dona Mariana também repele aqueles que lhe são próximos, pois inspira medo. A loucura que a acomete ao final da narrativa torna-a ainda mais monstruosa, mais assustadora. Retirando-se definitivamente do território das "pessoas normais", sela qualquer possibilidade de contato humano, à exceção de Carlota, pois é na loucura que ambas se encontram. Alforriando os escravos do Grotão e se recusando a um casamento 
arranjado pelo Comendador, Carlota terá atitudes que podem ser consideradas loucas pelo viés patriarcalista ou, como mencionado, monstruosas, pois destroem o sistema no Grotão, tornando-o improdutivo.

No retorno de Dona Mariana à fazenda, após ter sido expulsa pelo marido, invertem-se os papéis e é a filha quem passa a cuidar da mãe doente. Na verdade, essa inversão já vinha ocorrendo de forma gradual. À medida que Carlota se distancia do pai e da sua ordem patriarcal e escravocrata, faz um movimento de transformação em direção à mãe e passa a protegê-la, a cuidar de sua memória. Pouco a pouco se torna afetuosa com a Senhora e destruidora em relação ao pai, porque vai de encontro àquilo que ele preservava. Deformada e silenciada pelo discurso do Comendador, inicialmente Dona Mariana parece distante às suas filhas. No entanto, Carlota rompe com o "círculo mágico" que lhe turvava a visão, aproxima-se da mãe e se torna ela também destruidora do patriarcalismo. A filha é criatura de sua criadora e recria a mãe nas próprias atitudes: o monstro se reproduz (NAZÁRIO, 1999: p.39). A capacidade de se expandir, de se multiplicar é outra característica monstruosa. Procriando, o monstro indica que se perpetuará, que não será detido.

O Dr. Viktor Frankenstein, como Dona Mariana, também se afasta da sua criação, mas por motivos muito diversos. Imediatamente após "dar à luz", o jovem cientista é acometido de uma crise de horror e repulsa, por aquele ser que tanto o atraira. O desejo de eternizar o ser humano e, por extensão, de se eternizar na sua obra - como muitos pais desejam permanecer através dos filhos - cai por terra ao se deparar com a criatura:

Eu tinha trabalhado duramente por quase dois anos, com o único objetivo de infundir vida a um corpo inanimado. Privei-me de descanso e de cuidar da saúde. Era algo que eu desejava com um ardor que excedia em muito qualquer moderação; mas agora que tinha terminado, a beleza do sonho se desvanecera, e horror e desgosto sufocantes enchiam meu coração. Sem poder suportar o aspecto do ser que eu criara, saí correndo da sala e fiquei andando de um lado para outro em meu quarto, incapaz de acalmar minha mente para dormir. (SHELLEY, 2006: p.65)

Resistente ao calor e ao frio, descomunalmente forte e agigantada, a criatura se sobrepõe inclusive ao seu criador. Frankenstein é um Prometeu moderno, não por acaso o subtítulo do romance. Gerando um novo homem, ele tenta ser um deus, tenta imitar a atitude divina. Mas não passa de um simulacro, que seria, segundo Deleuze, "o acto 
pelo qual a própria ideia de um modelo ou de uma posição privilegiada é contestada, destruída" (DELEUZE, 2000: p.140). Mary Shelley declara na Introdução da Autora: "Horrendo, é só o que ele pode ser, pois supremamente horrendo seria o efeito de qualquer esforço humano de caricaturar os estupendos desígnios do Criador" (SHELLEY, 2006: p.15). A rigor, Frankenstein cria um mundo sem Deus, pois num mundo em que qualquer um pode criar, não há mais Deus - o modelo foi irremediavelmente perdido. O novo homem não é um ser perfeito, não é um Adão.

Apesar de seu caráter remeter a um princípio de integridade, a criatura é feita a partir de restos de diversos cadáveres. Além de conferirem um aspecto assustador e deformado, esses restos igualmente remetem a uma constituição metonímica - como Dona Mariana, a criatura é regida por uma idéia de fragmentação e, portanto, inapreensível. Nem a resistência, nem a força, nem o tamanho são de fato qualidades, pois ela foge ao domínio do seu criador. Frankenstein não possui qualquer ascensão sobre sua criatura e isso se dá porque no momento em que ela veio à luz ele a negou. Como o Prometeu grego, o cientista é castigado pelos deuses por ter ultrapassado a hybris - o monstro é novamente um aviso de que uma fronteira foi rompida. Numa conversa com Walton, um protetor, Frankenstein reconhece a desmedida do seu ato: "Você busca conhecimento e sabedoria, como eu também busquei; e eu ardentemente espero que a realização de seus desejos não venha a ser uma serpente a envenená-lo, como foi no meu caso" (SHELLEY, 2006: p.34). Até um certo ponto, até um certo limite, o conhecimento e a sabedoria podem ser benéficos, mas, quando o território divino é invadido, surge o monstro e a imagem bíblica da serpente envenenadora só reforça esse aspecto.

Outro vínculo entre D. Mariana e Frankenstein é o tema da sexualidade. Costa Lima afirma que o erótico está ausente em A menina morta e que, em seu lugar, está a culpa. Segundo o crítico, trata-se da ocupação de um lugar ilegítimo, advinda do duplo ou da duplicidade, que propicia a culpa (LIMA, 1976: p.186). Não se discutirá imediatamente, e sim adiante, se o sentimento de culpa provém ou não do duplo e da conseqüente ilegitimidade de lugares ocupados. Mas não se pode concordar com a idéia de ausência do erótico. O Comendador é flagrado em passeios clandestinos a altas horas da noite em direção à parte feminina da senzala. Ele próprio é objeto do desejo da filha, num momento incestuoso singular na obra de Cornélio Penna, Carlota 
Viu então com ansiosa surpresa que ele era ainda o mesmo homem belo e ágil sempre visto em seus sonhos, quando meditava lá no Colégio (...). Prestou melhor atenção, enquanto ele estava ainda de costas e detalhou então a sua nuca muito lisa e vigorosa, as suas orelhas vermelhas, a sua pele de tom quente e moreno. Lembrou-se de ter dito às suas amiguinhas, na recreação, ser seu pai o homem mais bonito do mundo, e sentiu de repente inquieta vergonha, que fez vir aos seus olhos lágrimas ardentes e rápidas, e tolhida pela confusão, não pôde sequer ocultá-las. (PENNA, 1997: p.248)

E a sexualidade pode ir além, pois Dona Mariana tem um envolvimento com Florêncio, um escravo, que parece ultrapassar os limites da indignação diante de injustiças. Florêncio tenta assassinar o Comendador. Frustrado o crime, o rapaz é capturado a mando do Senhor, quando se forja um suicídio grosseiro. Dona Mariana, visivelmente transtornada, solicita diante de todos os moradores da fazenda que o padre da vila próxima encomende o corpo do escravo morto. O padre afirma já tê-lo feito. Todavia, sabe-se que suicidas jamais teriam seus corpos encomendados. A atitude de Dona Mariana e do padre revela publicamente que Florêncio não se suicidara, mas fora assassinado por vingança do Comendador. A rebelião não ficará impune, a Senhora será imediatamente afastada do Grotão e só retornará louca ao final da narrativa, como já mencionado.

Uma leitura atenta revela um elo ainda maior entre Dona Mariana e Florêncio distante dos outros escravos, visto saltando janelas da casa-grande à noite e negado em casamento pela Senhora a Libânia, "mucama de dentro" (PENNA, 1997: p.215-216). De que natureza é esse elo é difícil concluir, mas não conjeturar: ou Florêncio estava a serviço de Dona Mariana para eliminar seu marido ou ambos teriam uma relação mais pessoal - o que parece mais plausível e justifica melhor o silêncio dela diante do pedido de casamento da mulata. Claro que a relação sexual entre uma branca rica e um escravo mulato é socialmente interdita, o que não significa que ela não se realize enquanto transgressão - portanto mais fronteiras sendo ultrapassadas e monstruosidades sendo geradas.

Com o Dr. Viktor Frankenstein, o caso é um pouco outro. Em primeiro lugar, o cientista "dá à luz" sendo homem, e não mulher; segundo, a criatura é gerada sem sexo - fatos que indicam nova fronteira transposta. E, terceiro, não gerando uma segunda criatura, uma fêmea, como o macho desejava, Frankenstein interdita a sexualidade da criatura, ainda que outros problemas estejam em jogo. 
(A fêmea) poderia vir a ser dez mil vezes mais malévola que seu companheiro, deleitando-se em matar e destruir só pelo prazer de fazê-lo. Ele jurara deixar para sempre as proximidades da humanidade e se esconder nas regiões ermas, mas ela não; e ela, que com toda probabilidade seria um animal pensante, capaz de raciocinar, poderia se recusar a cumprir um juramento feito antes de sua criação. Eles poderiam até mesmo odiar um ao outro; a criatura que já vivia odiava sua própria deformidade; não seria ele capaz de desenvolver um ódio ainda maior de sua feiúra quando a visse a sua frente na forma de uma fêmea? Ela também poderia rejeitá-lo, em face da superior beleza dos homens; ela poderia abandoná-lo, e ele ficaria de novo sozinho e exasperado por mais essa provocação, a rejeição de alguém de sua mesma espécie.

Mesmo se eles realmente deixassem a Europa e fossem morar nas paragens desertas do Novo Mundo, um dos primeiros resultados desses sentimentos pelos quais o demônio ansiava seria ter filhos, e uma raça de diabos se propagaria pela Terra, podendo transformar numa condição precária e cheia de terror a própria existência da espécie humana. (SHELLEY, 2006: p.183184)

Conseqüentemente, o monstro não desfrutará dos prazeres do corpo e não poderá procriar. Frankenstein teme o poder aniquilador da multiplicação, teme a potencial sexualidade do ser gerado. Por sua vez, a criatura faz o mesmo, matando a noiva do criador na noite de núpcias. Surge daí uma relação ambígua entre criador e criatura: novamente, quem é a vítima e quem é o monstro? É como se um vivesse em função do outro, ou melhor, é como se um morresse em função do outro, visto que se destroem reciprocamente. A ambigüidade entre eles é mais uma vez ressaltada, se destroem porque se perseguem, mas se intercalam na posição de caçador e caça: ora é a criatura quem busca o cientista e ora é este quem busca de maneira frenética a criação.

Portanto, o criador e a criatura se configuram enquanto duplos, um reproduz o outro e Frankenstein tem consciência disso, pois afirma sobre o monstro que ele é o “meu próprio vampiro, meu próprio espírito libertado da tumba e forçado a destruir tudo o que me era caro" (SHELLEY, 2006: p.86) Em última instância, foi o próprio cientista quem o forçou a isso. Após aprender a falar por seus próprios meios, a criatura se expressa numa linguagem culta semelhante à do seu criador. Ambos são monstros, pois ambos destroem. E, sobretudo, ambos se fundem, pois são tratados por um mesmo nome: Frankenstein.

Segundo Otto Rank (2001), o duplo é um aviso de morte. Já se viu que o monstro também é uma advertência de que um limite foi ultrapassado. Portanto, o duplo 
é um tipo de monstro que atormenta aquele que duplica, como ocorre entre Frankenstein e a criatura. Pode-se dizer ainda que o duplo, como o simulacro, apaga ou turva a idéia de origem. Quando se analisa a monstruosidade que o duplo propõe, torna-se impossível estabelecer qual o original e qual a cópia. É óbvio afirmar que a criatura foi gerada a partir de Frankenstein, mas também se pode dizer que este se torna fruto daquela na medida em que passa a agir em função da sua existência. $\mathrm{O}$ ser do cientista passa a ser definido e moldado pelo ser que ele gerou. Não é apenas a criatura que vive em torno do criador, mas este também vive em torno do ser engendrado. Por isso Frankenstein só pode ser um simulacro de Deus, ele não é e não pode ser a essência a partir da qual tudo se fez. Frankenstein apenas tenta repetir aquilo que outros já haviam tentado antes dele: criar. Mas criar a beleza seria uma prerrogativa da divindade e não de um mortal, reconhece a criatura: "Deus, piedoso, fez o homem belo e fascinante, à sua própria imagem; mas a minha forma é uma contrafação repulsiva da sua" (SHELLEY, 2006: p.146).

A duplicidade igualmente se dá entre Dona Mariana e suas filhas, mas, nesse caso, serve para aumentar a potência destrutiva, porque a oposição que há entre elas fica circunscrita ao nível das aparências. Todas as três embaralham papéis: são vítimas e monstros, caças e caçadoras do patriarcalismo. $\mathrm{O}$ aviso de morte que dão não é de uma para as outras, mas para o sistema que as gerou. Todas se repetem umas nas outras na forma como são denominadas: menina mORTA, CarlOTA e SenhORA. Refletem-se e se espelham, são semelhantes mas não são idênticas. A rima, segundo Deleuze, é marca de repetição e diferença (DELEUZE, 2000: p.71). Senhora, menina morta e Carlota são palavras que se sobrepõem, portanto se repetem, mas não integralmente, porque então seriam as mesmas. A rima só é possível quando algo permanece e algo se modifica. $\mathrm{O}$ monstro se revitaliza no seu poder de transformação. É na modificação que ele se torna não reconhecível e inapreensível, portanto não se deixa capturar.

A duplicidade entre Dona Mariana e suas filhas termina por gerar identidade entre elas, mas nenhuma identidade se firma no absolutamente igual, daí serem denominadas de maneira semelhante mas não idêntica - sempre repetição e diferença. $O$ local do encontro da identidade é o local da semelhança, é o momento fugaz em que um se vê no outro. É no espelho da memória que uma personagem se vê refletida na outra, pois na narrativa elas nunca se encontram: quando Carlota chega ao Grotão de volta de anos de estudo na Corte, a menina já está morta e Dona Mariana se fora. Há algo de 
reconfortante e ao mesmo tempo de aterrorizante no olhar capaz de se perceber repentinamente na memória do gesto de um outro. Novamente a idéia de origem e cópia ou de criador e criatura se vêem embaralhadas, como no anagrama que pode ser visto no vocativo MeNInA moRtA, onde se lê de forma fragmentada, descontínua e desconstruída: MARIANA. Mais do que a herança genética ou moral, a criança falecida traz em si o nome da mãe. A “figura mutilada" (PENNA, 1997: p.290), já mencionada anteriormente, que Carlota guarda na memória da infância reaparece na irmã morta, na forma como ela é denominada. As filhas repetem o ato destruidor da Senhora, mas esta também repete as filhas, antecipa seus futuros pouco promissores. Dona Mariana, oprimida pelo marido, sente-se indignada diante da escravidão, é o retrato daquilo que aguardavam a menina morta, se não morresse tão jovem, e Carlota, se houvesse se casado.

O potencial destrutivo que Dona Mariana e suas filhas engendram é antagônico à aparente busca de civilização e progresso empreendida pelo Comendador e atestada nas armas da família: Spes et labor (PENNA, 1997: p.116). De esperança, num futuro melhor, e de trabalho seria feita essa empresa. Claro está que a labuta exaustiva e rígida do dia-a-dia ficaria nas mãos calejadas dos escravos, ao Senhor caberia o comando. Paradoxalmente, aqueles que são considerados bárbaros, os negros e mulatos, serão os responsáveis pelo enriquecimento do Grotão - e do Brasil. São eles que possibilitarão o acúmulo, senhor do ócio, que por sua vez dá espaço ao progresso, à civilização e ao requinte que espocava pouco a pouco no século 19.

Porém, forças contrárias não cessam de atuar. Dona Mariana e suas filhas só por serem mulheres já estão indissociavelmente ligadas à Natureza. A narrativa aponta essa indissociabilidade em vários momentos e é a clareira que sintetiza melhor essa ligação. Se a memória é o tempo no qual as três se encontram, a clareira é o espaço que as reúne. O lugar é extremamente privilegiado: fora nela que a família de Dona Mariana, ainda criança, parara por acaso para descansar durante uma viagem. É ali que seu destino se cruza com o do Comendador. É para a clareira que recorre sempre que deseja se isolar dos demais e, como dito anteriormente, é lá que se mantém uma capela de aspecto primitivo, cultuada por ela - e pelos escravos. Lugar preferido das brincadeiras da menina morta, é na clareira que Carlota pressente a presença da mãe. Portanto, é na clareira, um espaço de luz, no meio da mata, longe da casa-grande e do eito - espaços dominados pelo Comendador - que as três, finalmente, "se encontram". É importante 
destacar que, relacionadas à natureza tal qual é retratada no romance, Dona Mariana e suas filhas assumem contornos ainda mais devastadores, pois constantemente a paisagem é descrita como hostil. É como se a natureza estivesse sempre a postos, pronta a tomar de volta os campos que lhe foram roubados pelo plantio do café.

"O mundo apodreceu, envenenou-se de civilização", afirma Cornélio Penna (1958: xlvi). Para o autor de A menina morta, o conhecimento e o progresso são negativos. Esse romance foi publicado em 1954, numa década em que os apelos desenvolvimentistas tornavam-se cada vez mais fortes e que culminaria na construção de Brasília - símbolo metonímico do momento pelo qual o país passava. Cornélio Penna se posiciona claramente contrário a esses apelos. Escrevendo uma obra situada no século 19, quando a nação lançava suas primeiras bases, ele não se recusa a discutir o presente, mas opta por uma linguagem indireta, de certa forma, enigmática. Na verdade, para o escritor, a história se repete, busca-se o novo e o moderno e não se medem os danos causados nessa busca. Walter Benjamin já dissera que o progresso é "considerado como uma norma histórica" (BENJAMIN, 1994: p.226), um fim do qual não se poderia escapar, ou seja, uma visão teleológica dos fatos que, via de regra, se encaminhariam todos numa única direção. Mas, segundo Benjamin, para quem essa é uma idéia restritiva, outras coisas devem ser observadas:

Há um quadro de Klee que se chama Angelus Novus. Representa um anjo que parece querer afastar-se de algo que ele encara fixamente. Seus olhos estão escancarados, sua boca dilatada, suas asas abertas. O anjo da história deve ter esse aspecto. Seu rosto está dirigido para o passado. Onde nós vemos uma cadeia de acontecimentos, ele vê uma catástrofe única, que acumula incansavelmente ruína sobre ruína e as dispersa a nossos pés. Ele gostaria de deter-se para acordar os mortos e juntar os fragmentos. Mas uma tempestade sopra do paraíso e prende-se em suas asas com tanta força que ele não pode mais fechá-las. Essa tempestade o impele irresistivelmente para o futuro, ao qual ele vira as costas, enquanto o amontoado de ruínas cresce até o céu. Essa tempestade é o que chamamos progresso. (BENJAMIN, 1994: p.226)

O grande monstro para Benjamin, e para Cornélio Penna, é o progresso, é o futuro, ou simplesmente o presente, que é incapaz de se reconhecer na imagem distorcida que o passado compõe. O sistema do século 19 - já esgotado, é bem verdade - é o patriarcalismo escravocrata. Em A menina morta observa-se que esse sistema, que 
em tese gerava as riquezas da recente nação formada, deformava-a, pois também gerava monstruosidades como a violência e a exploração indiscriminada de negros e mulatos.

Nesse caso não serão Dona Mariana e suas filhas os monstros. Sempre mencionada com desdém por Dona Virgínia - como já se viu, uma das suas principais inimigas - a família da Senhora e ela própria são estranhas ao universo dos Albernaz. A propósito, o estranhamento é também uma das características do monstro, que é sempre o que veio de fora, o que não foi assimilado, o outro. Portanto, estranha aos Albernaz, a Senhora - e suas filhas, consideradas mais pertencentes a ela do que ao marido tornava-se alheia ao vampiresco, metáfora da exploração à qual os cativos eram sujeitados. Nesse aspecto o Comendador se transforma no verdadeiro monstro, mas ele não destrói suas vítimas, ele as parasita, pois necessita mantê-las vivas para sobreviver como morto-vivo que é. Numa narrativa que subverte a possibilidade de fundação de uma identidade nacional harmônica, isso não parece casual.

No romance de Shelley a oposição entre civilização e barbárie é igualmente nítida. O cientista busca de forma alucinada o conhecimento. Ele é quase um Fausto, que vende a alma em troca de juventude e ciência, ambas sintetizadas na configuração ambígua do monstro, visto que tanto poderia viver eternamente quanto simbolizaria o poder do conhecimento adquirido. O objetivo de Frankenstein parece bom, no entanto sua realização se revela um desastre, porque a criatura que simbolizaria o conhecimento e, por extensão, o progresso é facilmente identificada com a barbárie. Feito de restos de cadáveres, o monstro não aponta para o futuro, mas para o passado. O cientista ressuscita aquilo que já não é mais. A criatura vem à luz sem saber falar, sem qualquer domínio sobre o mundo. É um ser primitivo. Fisicamente horrendo e com atitudes assassinas, o recém-nascido é um monstro e um monstro é aquele que não se conhece ou não se quer conhecer - ou não se quer reconhecer. A barbárie que engendra é a barbárie contida em todo o ser humano, é tudo aquilo que o "gentleman" Frankenstein forceja por não ser - ou por não reconhecer que é. É quando o estranho se torna familiar (FREUD, 1976). A narrativa apresenta de forma depreciativa a busca pelo conhecimento e pelo progresso - o que também se percebe em A menina morta. O cientista passou da medida, ultrapassou a hybris, como para os antigos gregos, e será punido de forma exemplar. Ele próprio se penitencia pela sua vaidade excessiva caçando um monstro que com certeza o destruirá. E na hora da morte aconselha Walton, seu protetor, para que "Procure sua felicidade na paz, e evite a ambição, mesmo se for 
aquela aparentemente inocente de se distinguir em ciência por suas descobertas. Mas por que digo isso? Eu mesmo vi minhas esperanças arruinadas, mas um outro bem pode ter sucesso" (SHELLEY, 2006: p.241 - grifo meu). Essa declaração abre uma porta ao final da narrativa quase inusitada. Pela primeira e única vez a "mensagem" geral da ciência como negativa aparece com o sinal invertido. No entanto, é um moribundo praticamente ensandecido que fala da sua criação como um fracasso e da possibilidade de que outro lograsse êxito. De maneira que a frase é desautorizada pelo contexto. Além disso, a morte de Frankenstein e a promessa da criatura de suicídio assinalam de forma inegável a punição e reforçam a idéia de que somente as criações divinas podem frutificar - as humanas são monstruosidades.

Fronteiras entre civilização e barbárie são rompidas pelo monstro. Ele surge como novo aviso de que houve transgressão a uma regra, a uma lei. Em Frankenstein essa lei é muito clara: o cientista penetrou num território que não lhe dizia respeito, pretendendo um ato da mais elaborada civilização, criou um ser bárbaro. A menina morta não é muito diferente. O Comendador - e todos os proprietários de escravos pretende ser um homem culto e refinado, que vive rodeado de luxo. Todavia, o que sustenta essa aparência é o trabalho árduo de pessoas consideradas bárbaras. Dona Mariana e suas filhas surgem então como monstros, como advertências de que o Senhor ultrapassou todos os limites. Como quem passou da medida foi ele e não elas, é o Comendador o verdadeiro monstro. Assim como é Frankenstein o monstro e não sua criatura, é o cientista que desejou atingir um patamar que lhe estava previamente negado pelas forças da natureza. O romance de Shelley fala do mal-estar da humanidade diante do avanço da ciência e do progresso tecnológico (JEHA, 2007: p.7). A sua maneira, A menina morta faz o mesmo.

\section{Referências Bibliográficas:}

BENJAMIN, Walter. Sobre o conceito da História. In: Magia e técnica, arte e política: Ensaios sobre literatura e história da cultura. Trad. Sérgio Paulo Rouanet. 7. ed. São Paulo: Brasiliense: 1994. p. 222-232.

CARDOSO, Marília Rothier. In: PENNA, Cornélio. Fronteira. Rio de Janeiro: Artium, 2001.

CARROLL, Noël. A filosofia do horror ou paradoxos do coração. Trad. Roberto Leal Ferreira. Campinas: Papirus, 1999. 
COHEN, Jeffrey Jerome. A cultura dos monstros: sete teses. In: SILVA, Tomaz Tadeu da (org.). Pedagogia dos monstros: Os prazeres e os perigos da confusão de fronteiras. Belo Horizonte: Autêntica, 2000. p. 23-60.

DELEUZE, Gilles. Diferença e repetição. Trad. Luiz Orlandi e Roberto Machado. Lisboa: Relógio D’Água, 2000.

FREUD, Sigmund. O estranho. In: Além do princípio do prazer. Trad. José Octávio de Aguiar Abreu. Rio de Janeiro: Imago, 1976. v. 18.

JEHA, Julio. Apresentação: Monstros: a face do mal. In: JEHA, Julio (org.). Monstros e monstruosidades na literatura. Belo Horizonte: Ed. UFMG, 2007. p. 7-8.

LIMA, Luiz Costa. A perversão do trapezista: O romance em Cornélio Penna. Rio de Janeiro: Imago, 1976.

LIMA, Luiz Costa. O romance em Cornélio Penna. 2. ed. rev. e modificada. Belo Horizonte: Ed. UFMG, 2005.

NAZÁRIO, Luiz. Da natureza dos monstros. São Paulo: Arte \& Ciência, 1998.

PENNA, Cornélio. Romances completos. Rio de Janeiro: Aguilar, 1958.

PENNA, Cornélio. A menina morta. Rio de Janeiro: Artium, 1997.

RANK, Otto. Don Juan et le double. Trad. S. Lautman. Paris: Petite Bibliothèque Payot, 2001.

SANTOS, Josalba Fabiana dos. Fronteiras da nação em Cornélio Penna. Belo Horizonte, 2004. Tese (Doutorado em Estudos Literários) - Universidade Federal de Minas Gerais.

SANTOS, Josalba Fabiana dos. Monstros e duplos em A menina morta. In: JEHA, Julio (org.). Monstros e monstruosidades na literatura. Belo Horizonte: Ed. UFMG, 2007. p. $125-145$.

SCHLAFMAN, Léo. O outro lado da fronteira. In: PENNA, Cornélio. Fronteira. Rio de Janeiro: Artium, 2001.

SHELlEY, Mary. Frankenstein. Trad. Marcos Maffei. São Paulo: Ática, 2006. 